\title{
Implementing Project Management Category Process Areas of CMMI Version 1.3 Using Scrum Practices, and Assets
}

\author{
Ahmed Bahaa Farid \\ Faculty of Computers and \\ Information \\ Helwan University \\ Cairo, Egypt
}

\author{
A. S. Abd Elghany \\ Faculty of Business Administration \\ Higher Technological institute \\ $10^{\text {th }}$ Ramdan, Egypt
}

\author{
Yehia Mostafa Helmy \\ Faculty of Commerce \& Business \\ Administration \\ Helwan University \\ Cairo, Egypt
}

\begin{abstract}
Software development organizations that rely on Capability Maturity Model Integration (CMMI) to assess and improve their processes have realized that agile approaches can provide improvements as well. CMMI and agile methods can work well together and exploit synergies that have the potential to improve dramatically business performance. The major question is: How to realize the integration of these two seemingly different approaches? In an earlier work, we have conducted a field study within six companies. These companies worked with agile methods for years and the Egyptian Software Engineering Competence Center (SECC), which is the regional CMMI appraisal center, assessed them. This study was mainly conducted to enhance the empirical understanding in this research field. Additionally, it showed that companies usually don't use agile in a good way that helps in covering the CMMI specific practices. In this paper, we present a new approach for mapping between CMMI and Scrum method. This mapping has been analyzed, enhanced, and then applied to the same companies. Putting in considerations that other previous efforts have worked in the same context but for an older version of CMMI, our research is using the latest CMMI version, which is 1.3. The research shows that our mapping approach has resulted in $37 \%$ satisfaction and achieved $17 \%$ partial satisfaction for CMMI specific practices. This resembles $19.4 \%$ enhancement in the satisfaction, and $6.2 \%$ improvement in the partial satisfaction against the previous related research effort that was already not targeting the latest CMMI version.
\end{abstract}

Keywords-Software Engineering; Scrum Software development; Process Improvement; CMMI; Scrum; Scrum CMMI Mapping; Project Management CMMI Process Areas; CMMI-Dev version 1,3; CMMI Project Management Category

\section{INTRODUCTION}

Quality management systems (QMS) like ISO 19011, CMMI or SPICE, have been a quite popular in the software industry since many years ago. This popularity comes from the fact that the improvement of development processes is empirically linked to the improvement of software quality. However, the documentation and formalization-overhead of those frameworks are massive. Many companies suffer from this overhead and desire more efficiency in development and project management while maintaining the high quality of their software products [1].
Lately, a new approach to the software development has gained a foothold in the software industry, which is called agile development. The agile manifesto [2], which was written in 2001, derived the term agile development. Agile processes have been proposed to overcome the flexibility issues of traditional procedures. Agile development methodology is an umbrella term that describes several agile methods such as Scrum, XP, ASD, Crystal, FDD, DSDM, and Lean. Most of the agile methods promote development iterations, teamwork, collaboration, and process adaptability throughout the lifecycle of the project [3]. Agile practices have been criticized for a lack of discipline and argued of being suitable only for some particular types of projects [4].

On one hand, companies that assess and improve their processes based on CMMI are now realized that agile approaches can provide simplification, improvements as well. On the other hand, there are increasing numbers of agile champion companies, which are looking for more structured processes [5]. For many software engineering schoolers, Agile methods and CMMI best practices are often perceived to be at odds with each other at first glance. This wide gap between two options is not the accurate picture. In 2008, the Software Engineering Institute (SEI) published a technical report that clarifies two reasons behind this inaccurate picture in some engineers' minds. The first reason is the early adopters of both approaches came from different software development paradigms. The second reason lies in the misuse of both perspectives that resulted in misperceptions in both camps about the another [6]. Therefore, the question has to be raised if these two seemingly different approaches could be combined with each other and if the combination brings more benefits than either one alone.

In [7] we have explained a conducted empirical study to check the value of simplifying CMMI version 1.3 through using some agile practices while enhancing it with non-agile ones. The Study primary objective was to increase the understanding of CMMI and agile integration and to explore the reconciliation of these two approaches. The previously mentioned research showed that Scrum practices (as one of the Agile methods) with non-scrum improvements could satisfy the CMMI process areas' specific practices. This means that an organization that uses Scrum without any 
further improvements would not be able to achieve capability level 2 on Project Planning (PP), Project Management and Control (PMC), Requirements Management (REQM), Risk Management (RSKM), and Integrated Projected Management (IPM). However, Scrum could be used, and enhanced with other agile techniques. To make this possible, some objectives have to be achieved. First, Scrum practices have to be mapped to the CMMI specific practices; one-by-one to have a better understanding of the relation between CMMI and Scrum. To achieve the latter goal, it is important to study the scrum coverage to the Project Management (PM) category process areas, and to identify the earliest scrum methods that have a significant contribution in satisfying the CMMI specific practices [8], [9], [10].

According to the Forrester state of agile development report $65 \%$ of mid-sized enterprises (with less than 1000 employees) has reported that $100 \%$ of their teams uses agile for their software development. $85 \%$ of the agile adaptors embraces scrum as their applied agile method [11]. Having a systematic way that could enhance satisfying the CMMI certification using the commonly used scrum practices and assets could help more than $55 \%$ ( $85 \%$ of the $65 \%$ ) of the mid-sized enterprises to get, or keep their CMMI certification. Some previous efforts tried to provide some ways to do this for CMMI Version 1.2 in some CMMI process areas. Some other process areas (i.e the process areas of Project Management) have not touched in previous research efforts. This paper shows how the scrum practices and assets could cover the Project-Management category's process areas of CMMI 1.3 with the use of normal scrum practices and assets without any extra enhancements.

The paper is organized as follows: Section 2 presents the background overview of CMMI and Scrum. Section 3 focuses on describing the problem- solving approach that is used to do the research. Section 4 presents the conducted research activities. Section 5 discusses the paper results against previous work that has been carried out by another previous research. The last section concludes the paper with final remarks.

\section{BACKGROUND OVERVIEW}

\section{A. Project Management Category of CMMI}

The focus of this paper is on the project management category that covers the management activities that are related to planning, monitoring, and controlling the project. Table 1 shows the project management-related process areas grouped by its maturity levels [12], [13], [14].

TABLE I. CMmi Project Management Process AREaS

\begin{tabular}{|l|l|}
\hline Level & Process Area \\
\hline 2 & $\begin{array}{l}\text { Project Monitoring and Control (PMC) } \\
\text { Project Planning (PP) } \\
\text { Requirements Management (REQM) } \\
\text { Supplier Agreement Management (SAM) }\end{array}$ \\
\hline 3 & $\begin{array}{l}\text { Integrated Project Management (IPM) } \\
\text { Risk Management (RSKM) }\end{array}$ \\
\hline 4 & Quantitative Project Management (QPM) \\
\hline
\end{tabular}

Project Planning (PP)
The purpose of project planning (PP) is to establish and maintain plans that define project activities [15], [16], [17], [18], [19], [20], [21]. PP contains three specific goals (SG): SG 1 "establish estimates", SG 2 "develop a project plan", and SG 3 "obtain commitment to the plan", enclosing 14 specific practices (SPs).

\section{Project Monitoring and Control (PMC)}

The purpose of project monitoring and control (PMC) is to provide an understanding of the project's progress so that appropriate corrective action is taken when the project's performance deviates significantly from the plan [22]. PMC contains two specific goals: SG 1 "monitor project against plans" and SG 2 "manage corrective action to closure", enclosing ten specific practices [23], [24], [25], [26], [27].

\section{Requirements Management (REQM)}

The purpose of requirements management (REQM) is to manage requirements of the project's products and product components and to ensure alignment between those requirements and the project's plans and work products [28]. REQM has one specific goal: SG 1 "manage requirements", enclosing five specific practices.

\section{Integrated Project Management (IPM)}

The purpose of Integrated Project Management (IPM) is to establish and manage the project and the involvement of relevant stakeholders according to an integrated and defined process that is tailored from the organization's set of standard processes [29]. The specific goals of the IPM are SG 1 "use the project's defined process" and SG 2 "coordinate and collaborate with relevant stakeholders".

\section{Risk Management (RSKM)}

The purpose of risk management (RSKM) is to identify potential problems before they occur so that risk handling activities can be planned and invoked as needed across the life of the product or project to mitigate adverse impacts on achieving objectives [30]. The specific goals of the RSKM are SG 1 "prepare for risk management", SG 2 "identify and analyze risks", and SG 3 "mitigate risks".

\section{Supplier Agreement Management (SAM)}

The purpose of supplier agreement management (SAM) is to manage the acquisition of products from suppliers [31]. The specific goals of the RSKM are SG 1 "establish supplier agreements" and SG 2 "satisfy supplier agreements".

\section{Quantitative Project Management (QPM)}

The purpose of quantitative project management (QPM) is to quantitatively manage the project to achieve the project's established quality and process performance objectives [32]. The specific goals of the QPM are SG 1 "prepare for quantitative management" and SG 2 "quantitatively manage the project". Scrum does not mention practices to address this process area. Therefore, all of its practices are unsatisfied.

\section{B. Related Work}

CMMI and agile methods have been compared in several studies [33] and mappings between agile and CMMI practices have been proposed [34]. For example, Fritzsche and Keil analyzed [22] in their study which CMMI process areas can be covered by Scrum and XP. Unfortunately, most of the findings 
were not clearly derived and they did not provide empirical evidences. On the other hand, Pikkarainen and Mäntyniemi proposed an approach for assessing agile software development by using CMMI. However, only two process areas were covered (PP and REQM) and only from a CMMI goal (not specific practice). Marcal et al. [32], in turn, presented a more detail mapping between CMMI project management process areas and Scrum practices, but they did not provide empirical evidences.

Finally, Diaz et al. [35], [36], [37] presented a mapping between Scrum practices and three process areas (PP, PMC, and REQM). In addition, they reported empirical results that provide evidences that those process areas were largely covered. However, the mapping presented was high level and the use of the now outdated CMMI-DEV Version 1.2 limited the results. Unlike these researches, our work tries to increase the detail of the previous mapping between CMMI and Scrum, and to cover the process areas related to the higher maturity levels (IPM, RSKM, and QPM) in CMMI-DEV Version 1.3 which is the latest version up till now. In addition, we consider in our study not only the CMMI specific goals, but also the specific practices. Furthermore, a complete view of the CMMI project management process areas covered by Scrum practices will be established.

\section{PROBLEM SOLVING APPROACH}

\section{A. Research Questions}

The study that has been conducted in [7] was the base for a further research to discover the answers of some questions. First, which of the CMMI process areas could be satisfied by Scrum? Second. Which scrum assets could cover this satisfaction? Third, By which percentage this satisfaction coverage happens? Fourth, What are the most prior scrum assets to be considered when trying to cover CMMI using scrum? Fifth, what are the major gaps that are still there? Finally, which process areas are in conflict?

\section{B. Defining Problem Solving Approach}

In order to answer research questions; the study has been designed to be accomplished on Five steps that are all limited by the Project Management category's Process Areas (PAs) of CMMI-Dev Ver. 1.3. First, reviewing the available scrum assets that have to be studied in order to discover what are the possible ones that could be used to be mapped to the available specific practices (SPs) of CMMI-Dev Ver 1.3. Second, based on the reached mapping between scrum assets and CMMI practices, for the sake of a better understanding, a matrix should be developed to show all possible mappings between Scrum practices and CMMI-Dev SPs within the PM category. Third, according to the developed mapping matrix, the scrum coverage for CMMI SPs should be calculated according to a set of well-defined functions. This will help in finding out what are the prior scrum practices to take care of, when it is needed to streamline CMMI implementation using scrum. Discovering the prior scrum practices is the fourth designed step in this study. Finally, The results should be discussed, and compared to other related work to define the percentage of enhancement (if any) this study may achieve. The whole study has been applied on 6 companies out of the CMMI certified companies in Egypt and that are appraised by the regional CMMI center in Cairo that is called Software Engineering Competency Center (SECC).

\section{STUdy ACTIVITIES}

\section{Step 1: Mapping Scrum assets to the corresponding CMMI SPs:}

During the study, we analyzed each CMMI project management process area and all of its specific goals and practices in details and compared them with known Scrum practices. Table 2 depicts how we could satisfy the specific practices of the PP process area through using Scrum Practices. Each mapping set (single raw in that table) shows the satisfaction rating at the last column. In case the mapped Scrum Practices could satisfy the corresponding CMMI's specific practice fully (Rating :S), Partially (Rating: PS). If the set of Scrum assets could not satisfy, the corresponding SP at all it is considered as unsatisfied and tagged in the table with Rating U. Table 3 shows the same idea of scrum assets mapping to the SPs of PMC process area. Table 6 shows this for the REQM process area while Table 7 shows this for the context of IPM process Area.

\section{TABle II. Mapping Between Pp Process Area Specific Practices} AND SCRUM PRACTICES

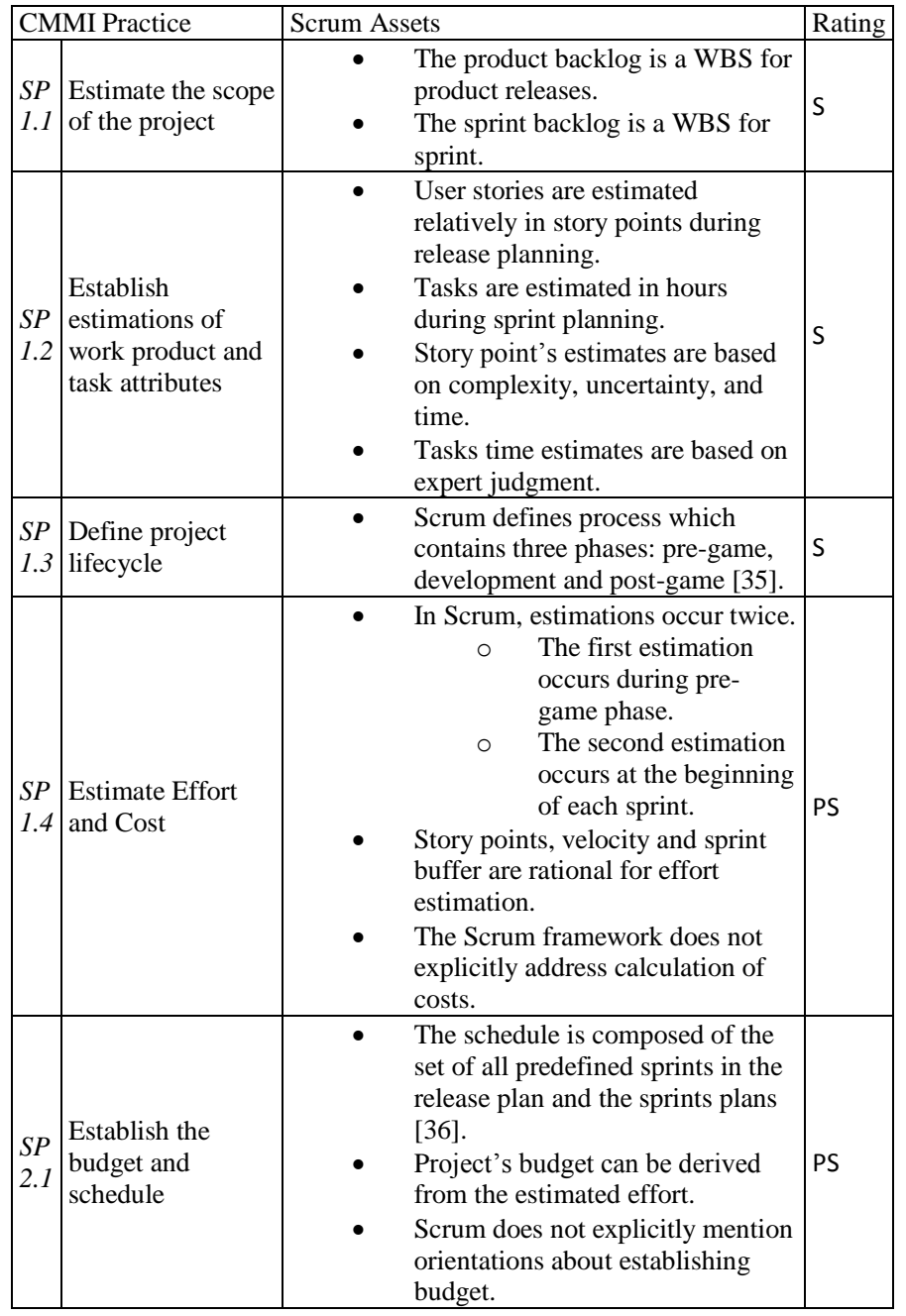


TABLE III. (CONTD.): MAPPING BETWEEN PP PROCESS AREA SPECIFIC PRACTICES AND SCRUM PRACTICES

\begin{tabular}{|c|c|c|c|}
\hline $\begin{array}{l}S P \\
2.2\end{array}$ & $\begin{array}{l}\text { Identify project } \\
\text { risks }\end{array}$ & $\begin{array}{l}\text { Risk identification is continually } \\
\text { done through release planning, } \\
\text { sprint planning, daily stand-ups, } \\
\text { and retrospective and review } \\
\text { meetings. } \\
\text { Risks are captured as impediments. } \\
\text { They are registered on white- } \\
\text { boards, flip charts, or impediments } \\
\text { list. } \\
\text { Risk assessment, categorization and } \\
\text { prioritization occur in an informal } \\
\text { manner [37]. }\end{array}$ & PS \\
\hline $\begin{array}{l}S P \\
2.3\end{array}$ & $\begin{array}{l}\text { Plan for data } \\
\text { management }\end{array}$ & $\begin{array}{l}\text { Scrum stores data in public folders } \\
\text { or white-boards which are available } \\
\text { for everyone that has a physical } \\
\text { access. } \\
\text { - Scrum does not address a formal } \\
\text { data management plan or } \\
\text { procedure. } \\
\text { Data privacy is another weakness } \\
\text { [1]. }\end{array}$ & $U$ \\
\hline $\begin{array}{l}S P \\
2.4\end{array}$ & $\begin{array}{l}\text { Plan for project } \\
\text { resources }\end{array}$ & $\begin{array}{l}\text { During the pre-game phase, the } \\
\text { project team, tools and other } \\
\text { resources are defined. } \\
\text { During the project, scrum master } \\
\text { ensures that the necessary resources } \\
\text { are available. }\end{array}$ & $\mathrm{S}$ \\
\hline $\begin{array}{l}S P \\
2.5\end{array}$ & $\begin{array}{l}\text { Plan for needed } \\
\text { knowledge and } \\
\text { skills }\end{array}$ & $\begin{array}{l}\text { At the start of a Scrum project, the } \\
\text { knowledge and skills needed to } \\
\text { perform the project are defined. } \\
\text { Knowledge and skills which are not } \\
\text { found in the organization are } \\
\text { considered as impediments and are } \\
\text { resolved during the daily and } \\
\text { retrospective meetings [33]. }\end{array}$ & $\mathrm{S}$ \\
\hline $\begin{array}{l}S P \\
2.6\end{array}$ & $\begin{array}{l}\text { Plan stakeholder } \\
\text { involvement }\end{array}$ & $\begin{array}{l}\text { Scrum defines roles, } \\
\text { responsibilities, and involvement of } \\
\text { the stakeholders during the } \\
\text { project's execution. } \\
\text { The scrum master is responsible for } \\
\text { ensuring that all stakeholders } \\
\text { involved in the project follow } \\
\text { scrum rules and practices. }\end{array}$ & $S$ \\
\hline $\begin{array}{l}S P \\
2.7\end{array}$ & $\begin{array}{l}\text { Establish the } \\
\text { project plan }\end{array}$ & $\begin{array}{l}\text { - The vision document, the product } \\
\text { backlog, the release plan, and the } \\
\text { sprint plan are considered as a } \\
\text { high-level plan for the project. }\end{array}$ & $S$ \\
\hline $\begin{array}{l}S P \\
3.1\end{array}$ & $\begin{array}{l}\text { Review plans that } \\
\text { affect the project }\end{array}$ & 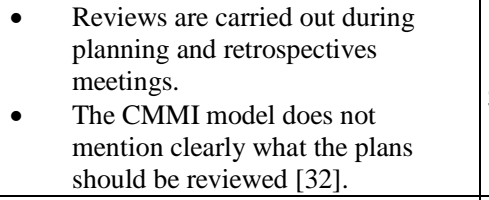 & $\mathrm{S}$ \\
\hline $\begin{array}{l}S P \\
3.2\end{array}$ & $\begin{array}{l}\text { Reconcile work and } \\
\text { resource levels }\end{array}$ & $\begin{array}{l}\text { Work reconciliation occurs during } \\
\text { the sprint planning meeting where } \\
\text { the team along with the product } \\
\text { owner define the work to be } \\
\text { developed in the sprint. }\end{array}$ & $S$ \\
\hline $\begin{array}{l}S P \\
3.3\end{array}$ & $\begin{array}{l}\text { Obtain plan } \\
\text { commitment }\end{array}$ & $\begin{array}{l}\text { - Commitment to the plan is obtained } \\
\text { iteratively at the beginning of each } \\
\text { sprint. } \\
\text { In the sprint planning meeting, the } \\
\text { team selects as much user stories as } \\
\text { it believes it can complete by the } \\
\text { end of the sprint. }\end{array}$ & $\mathrm{S}$ \\
\hline
\end{tabular}

TABLE IV.

Mapping Between PMc Process AReA's SPECIFIC Practices AND SCRUM PRACTICES

\begin{tabular}{|c|c|c|c|c|c|}
\hline \multicolumn{2}{|c|}{ CMMI Practice } & \multicolumn{3}{|c|}{ Scrum Assets } & \multirow{2}{*}{$\begin{array}{l}\text { Rating } \\
\text { PS }\end{array}$} \\
\hline $\begin{array}{l}S P \\
1.1\end{array}$ & $\begin{array}{l}\text { Monitor project } \\
\text { planning } \\
\text { parameters }\end{array}$ & & $\begin{array}{l}\text { This oc } \\
\text { retrosp } \\
\text { use of } \\
\text { On rele } \\
\text { comple } \\
\text { are mo } \\
\text { On spr } \\
\text { remain }\end{array}$ & $\begin{array}{l}\text { irs in the daily and } \\
\text { tive meetings and by the } \\
\text { rndown charts. } \\
\text { e level, velocity, } \\
\text { d points, and total scope } \\
\text { tored. } \\
\text { level, task effort and } \\
\text { g effort are monitored. }\end{array}$ & \\
\hline $\begin{array}{l}S P \\
1.2\end{array}$ & $\begin{array}{l}\text { Monitor } \\
\text { commitments }\end{array}$ & & $\begin{array}{l}\text { Comm } \\
\text { establis } \\
\text { meetin } \\
\text { the use } \\
\text { daily a }\end{array}$ & $\begin{array}{l}\text { nents to the plan are } \\
\text { ed during sprint planning } \\
\text { and monitored through } \\
\text { f burndown charts and } \\
\text { review meetings. }\end{array}$ & s \\
\hline $\begin{array}{l}S P \\
1.3\end{array}$ & $\begin{array}{l}\text { Monitor project } \\
\text { risks }\end{array}$ & & $\begin{array}{l}\text { Risks a } \\
\text { and are } \\
\text { standur } \\
\text { retrosp } \\
\text { Scrum } \\
\text { to defir } \\
\text { categor } \\
\text { manag }\end{array}$ & $\begin{array}{l}\text { captured as impediments } \\
\text { onitored through daily } \\
\text { neeting and } \\
\text { tives meeting. } \\
\text { es not mention practices } \\
\text { sources, parameters or } \\
\text { s to control the risk } \\
\text { lent effort [37]. }\end{array}$ & PS \\
\hline $\begin{array}{l}S P \\
1.4\end{array}$ & $\begin{array}{l}\text { Monitor data } \\
\text { management }\end{array}$ & & $\begin{array}{l}\text { The Sc } \\
\text { include } \\
\text { and tra }\end{array}$ & $\begin{array}{l}\mathrm{m} \text { framework does not } \\
\text { ny practices for planning } \\
\text { ing the project data. }\end{array}$ & $\mathrm{U}$ \\
\hline $\begin{array}{l}S P \\
1.5\end{array}$ & $\begin{array}{l}\text { Monitor } \\
\text { stakeholder } \\
\text { involvement }\end{array}$ & & $\begin{array}{l}\text { - } \\
\text { Stakeh } \\
\text { monito } \\
\text { during } \\
\text { Eviden } \\
\text { backlo } \\
\text { sprint b } \\
\text { fulfillir }\end{array}$ & $\begin{array}{l}\mathrm{d} \text { by the scrum master } \\
\text { oject meetings. } \\
\text { of updated impediment } \\
\text { product backlog and } \\
\text { cklog support the } \\
\text { of this practice [32]. }\end{array}$ & $\mathrm{s}$ \\
\hline $\begin{array}{l}S P \\
1.5\end{array}$ & $\begin{array}{l}\text { Conduct progress } \\
\text { reviews }\end{array}$ & & $\begin{array}{r}\text { - Reviey } \\
\text { done ol } \\
\text { O }\end{array}$ & $\begin{array}{l}\text { g project progress is } \\
\text { many levels: } \\
\text { On release level, it is } \\
\text { done through sprint } \\
\text { reviews, retrospectives, } \\
\text { and release plan. } \\
\text { On sprint level, it is } \\
\text { done through daily } \\
\text { standup meetings, task } \\
\text { boards, and sprint } \\
\text { burndown chart. }\end{array}$ & $\mathrm{s}$ \\
\hline
\end{tabular}

TABLE V. (CONTD.): MAPPING BetWEEN PMC PRocess AREA's SPECIFIC PRACTICES AND SCRUM PRACTICES

\begin{tabular}{|c|c|c|c|c|}
\hline $\begin{array}{l}S P \\
1.7\end{array}$ & $\begin{array}{l}\text { Conduct milestone } \\
\text { reviews }\end{array}$ & $\begin{array}{r}\text { In Scru } \\
\text { milesto } \\
\circ \\
0\end{array}$ & $\begin{array}{l}\text { there are two main } \\
\text { s: } \\
\text { Sprint milestone occurs } \\
\text { at the end of the sprint. } \\
\text { Release milestone } \\
\text { occurs when the team } \\
\text { has completed the } \\
\text { sprints in the release. }\end{array}$ & S \\
\hline $\begin{array}{l}S P \\
2.1\end{array}$ & Analyze issues & $\begin{array}{lr}- & \text { Collect } \\
\text { issues } \\
\text { standu } \\
\text { retrosp } \\
\text { - } \quad \text { Issues } \\
\text { board, }\end{array}$ & $\begin{array}{l}\text { and analyzing project } \\
\text { done either during daily } \\
\text { eetings or through } \\
\text { ives. } \\
\text { registered on a white } \\
\text { chart or impediment list. }\end{array}$ & S \\
\hline $\begin{array}{l}S P \\
2.2\end{array}$ & $\begin{array}{l}\text { Take corrective } \\
\text { action }\end{array}$ & $\begin{array}{l}\text { - } \quad \text { As mer } \\
\text { collect } \\
\text { daily a } \\
\text { - The tea } \\
\text { they ta } \\
\text { immed }\end{array}$ & $\begin{array}{l}\text { ned before, issues are } \\
\text { and analyzed during the } \\
\text { retrospective meetings. } \\
\text { could decide whether } \\
\text { the corrective actions } \\
\text { ely or they fix it in an }\end{array}$ & PS \\
\hline
\end{tabular}




\begin{tabular}{|c|c|c|c|}
\hline & & $\begin{array}{l}\text { upcoming sprint. } \\
\text { Scrum does not track how these } \\
\text { actions are planned, monitored and } \\
\text { implemented [32]. }\end{array}$ & \\
\hline $\begin{array}{l}S P \\
2.3\end{array}$ & $\begin{array}{l}\text { Manage corrective } \\
\text { action }\end{array}$ & $\begin{array}{l}\text { - Issues are registered on a white } \\
\text { board, flip chart or impediment list. } \\
\text { All corrective actions are } \\
\text { monitored until closing. } \\
\text { - The results are not analyzed to } \\
\text { determine their efficacy. }\end{array}$ & PS \\
\hline
\end{tabular}

TABLE VI. MAPPING BetweEn ReQm Process AREA's SPECIFIC PRACTICES AND SCRUM PRACTICES

\begin{tabular}{|c|c|c|c|}
\hline \multicolumn{2}{|c|}{ CMMI Practice } & Scrum Assets & Rating \\
\hline \begin{tabular}{|l|}
$S P$ \\
1.1
\end{tabular} & $\begin{array}{l}\text { Understand } \\
\text { Requirements }\end{array}$ & $\begin{array}{l}\text { The intense involvement of the } \\
\text { stakeholders guarantees a } \\
\text { common understanding of the } \\
\text { requirements to all people } \\
\text { involved [1]. } \\
\text { User stories can facilitate the } \\
\text { common understanding of the } \\
\text { requirements between the team } \\
\text { and the customer. }\end{array}$ & S \\
\hline \begin{tabular}{l|}
$S P$ \\
1.2
\end{tabular} & $\begin{array}{l}\text { Obtain } \\
\text { Commitment to } \\
\text { Requirements }\end{array}$ & $\begin{array}{l}\text { - Commitments to requirements are } \\
\text { made collectively by the whole } \\
\text { team through release planning and } \\
\text { sprint planning. } \\
\text { The obtaining of commitment is a } \\
\text { task of the Scrum master who can } \\
\text { take necessary actions to gain } \\
\text { commitment [1]. }\end{array}$ & s \\
\hline \begin{tabular}{l|}
$S P$ \\
1.3
\end{tabular} & $\begin{array}{l}\text { Manage } \\
\text { Requirements } \\
\text { Changes }\end{array}$ & $\begin{array}{l}\text { The product owner frequently } \\
\text { changes the user stories in the } \\
\text { product backlog and makes it } \\
\text { ready for the next sprint. } \\
\text { If a user that was already } \\
\text { implemented changed, a new story } \\
\text { is created and linked to its old } \\
\text { story. } \\
\text { The product owner and the team } \\
\text { discuss the changes to the user } \\
\text { stories in the sprint planning } \\
\text { meeting. }\end{array}$ & $\mathrm{s}$ \\
\hline \begin{tabular}{|l|}
$S P$ \\
1.4
\end{tabular} & $\begin{array}{l}\text { Maintain } \\
\text { Bidirectional } \\
\text { Traceability of } \\
\text { Requirements }\end{array}$ & $\begin{array}{l}\text { The hierarchy of Scrum } \\
\text { requirements formats - themes, } \\
\text { epics, user stories, and tasks - } \\
\text { supports the traceability among } \\
\text { the requirements. } \\
\text { If a user story dependent on } \\
\text { another, the first one is prioritized } \\
\text { higher than the second one. } \\
\text { Dependencies between user } \\
\text { stories are discussed in the daily } \\
\text { meeting or in the sprint planning } \\
\text { meeting. }\end{array}$ & $S$ \\
\hline \begin{tabular}{l|}
$S P$ \\
1.5
\end{tabular} & $\begin{array}{l}\text { Ensure that plans } \\
\text { and work products } \\
\text { remain aligned } \\
\text { with the } \\
\text { requirements }\end{array}$ & $\begin{array}{l}\text { - } \quad \text { Scrum backlogs help to ensure } \\
\text { constancy between plans and } \\
\text { requirements. } \\
\text { - The sprint backlog helps to ensure } \\
\text { that only the work that has been } \\
\text { committed will be implemented. } \\
\text { - No activities are implemented that } \\
\text { do not belong to a user story. } \\
\text { The definition of done (DOD) } \\
\text { supports constancy between work } \\
\text { products and plans. }\end{array}$ & $S$ \\
\hline
\end{tabular}

It is important to note that IPM process area, Scrum does not define a set of organizational standard processes, but it just establishes a set of practices and rules defined for the project. In other words, the project's defined process is not derived from a set of organizational processes. Therefore, all of the specific practices related to the Specific Goal 1 (SG1) are unsatisfied, except SP 1.6 "Establish Teams". Other specific practices of SG2 are satisfied, or partially satisfied as depicted in the table.

Concerning Risk Management (RSKM) process area, risks are captured as impediments and registered on white-boards, flip charts, or impediments list. However, scrum has no practices to define sources, parameters, or categories to analyze and control the risk management effort. Thus, risk assessment, categorization, and prioritization occur in an informal manner [37]. Therefore, all of the specific practices of RSKM are unsatisfied, except SP 2.1 (identify risks), because it is partially satisfied for the same reasons presented for PP SP 2.2.

For Supplier Agreement Management (SAM) Scrum does not mention practices to address the acquisition of products from suppliers. So, all of its specific practices are unsatisfied.

For Quantitative Project Management (QPM) Scrum does not mention practices to address this process area. Therefore, all of its practices are unsatisfied.

TABLE VII. MAPPING BETWEEN IPM PROCESS AREA's SPECIFIC PRACTICES AND SCRUM PRACTICES

\begin{tabular}{|c|c|c|c|}
\hline \multicolumn{2}{|c|}{ CMMI Practice } & Scrum Assets & Rating \\
\hline $\begin{array}{l}S P \\
1.6\end{array}$ & Establish Teams & $\begin{array}{l}\text { - In scrum, the well-defined } \\
\text { responsibilities of scrum roles } \\
\text { support team's establishment. } \\
\text { There are only three Scrum roles: } \\
\text { the product owner, the team, and } \\
\text { the Scrum master. } \\
\text { All management responsibilities } \\
\text { in a project are divided among } \\
\text { these three roles. }\end{array}$ & $S$ \\
\hline $\begin{array}{l}S P \\
2.1\end{array}$ & $\begin{array}{l}\text { Manage } \\
\text { Stakeholder } \\
\text { Involvement }\end{array}$ & $\begin{array}{l}\text { - Scrum practices and rules } \\
\text { implicitly define how } \\
\text { stakeholders will be involved in } \\
\text { the project. } \\
\text { This involvement is monitored by } \\
\text { the Scrum master }\end{array}$ & $S$ \\
\hline
\end{tabular}

TABLE VIII. MAPPING BETWEEN IPM PROCESS AREA's SPECIFIC PRACTICES AND SCRUM PRACTICES (CONTD.)

\begin{tabular}{|c|c|c|c|}
\hline $\begin{array}{l}S P \\
2.2\end{array}$ & $\begin{array}{l}\text { Manage } \\
\text { dependencies }\end{array}$ & $\begin{array}{l}\text { - Dependencies can be identified } \\
\text { through Scrum daily meetings. } \\
\text { The Scrum master is responsible } \\
\text { for resolving any identified } \\
\text { problem as soon as possible. } \\
\text { Scrum does not handle } \\
\text { coordination outside the Scrum } \\
\text { team. }\end{array}$ & PS \\
\hline $\begin{array}{l}S P \\
2.3\end{array}$ & $\begin{array}{l}\text { Resolve } \\
\text { coordination issues }\end{array}$ & $\begin{array}{l}\text { This practice is partially satisfied, } \\
\text { for the same reasons presented for } \\
\text { IPM SP } 2.2 \text {. }\end{array}$ & PS \\
\hline & & $\bullet$ & \\
\hline
\end{tabular}

Step 2: Mapping scrum practices to the appropriate CMMI Specific Practices 
Our study showed that a satisfaction matrix could be built to map some scrum practices to the CMMI specific practices of the Project Management (PM) related process areas. Figure 1 and figure 2 depict a resulting CMMI-Scrum Mapping satisfaction matrix that shows how the available scrum practices could be applied to the available CMMI practices.

\begin{tabular}{|c|c|c|c|c|c|c|c|c|c|c|c|c|c|c|c|c|c|c|c|}
\hline \multirow[b]{2}{*}{$\begin{array}{l}\text { CMMI } \\
\text { Practices }\end{array}$} & \multicolumn{19}{|c|}{ Scrum Practices } \\
\hline & 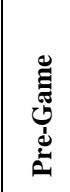 & 离 & 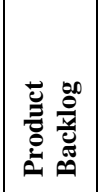 & 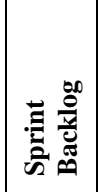 & 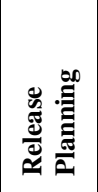 & 昜昜 & 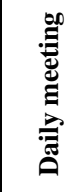 & 鄫高 & 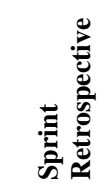 & 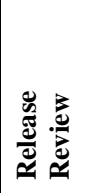 & 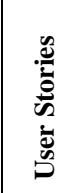 & 节 & 竞总 & $\begin{array}{l}\frac{3}{0} \\
\frac{0}{0} \\
\frac{0}{\partial}\end{array}$ & 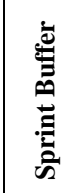 & لَّ & 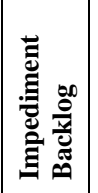 & 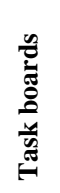 & 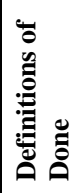 \\
\hline \multicolumn{20}{|l|}{$P P$} \\
\hline SP 1.1 & & & $x$ & $x$ & & & & & & & & & & & & & & & \\
\hline$S P P 1.2$ & & & & & $x$ & $x$ & & & & & $x$ & $x$ & & & & & & & \\
\hline$S P$ P 1.3 & & & & & & & & & & & & & $x$ & & & & & & \\
\hline$S P P 1.4$ & & & & & & & & & & & & $x$ & & $x$ & $x$ & & & & \\
\hline$S P$ P 2.1 & & & & & $x$ & $x$ & & & & & & & & & & & & & \\
\hline \begin{tabular}{|l|l|}
$S P$ & 2.2 \\
\end{tabular} & & & & & $x$ & $x$ & $x$ & $x$ & $x$ & & & & & & & & & & \\
\hline SP 2.3 & & & & & & & & & & & & & & & & & & & \\
\hline \begin{tabular}{|l|l|}
$S P 2.4$ \\
\end{tabular} & $x$ & & & & & & & & & & & & & & & & & & \\
\hline$S P 2.5$ & $x$ & & & & & & & & $x$ & & & & & & & & & & \\
\hline$S P 2.6$ & & & & & & & & & & & & & $x$ & & & & & & \\
\hline \begin{tabular}{|l|l}
$S P P 2.7$ \\
\end{tabular} & & $x$ & $x$ & & $x$ & $x$ & & & & & & & & & & & & & \\
\hline \begin{tabular}{|l|l}
$S P 3.1$ \\
\end{tabular} & & & & & & $x$ & & & $\bar{x}$ & & & & & & & & & & \\
\hline \begin{tabular}{|l|l|}
$S P$ & 3.2 \\
\end{tabular} & & & & & & $x$ & & & & & & & & & & & & & \\
\hline \begin{tabular}{|l|l}
$S P 3.3$ \\
\end{tabular} & & & & & & $x$ & & & & & & & & & & & & & \\
\hline
\end{tabular}

Fig. 1. Mapping matrix of suitable scrum practices to the PP specific practice of CMMI-Dev

\begin{tabular}{|c|c|c|c|c|c|c|c|c|c|c|c|c|c|c|c|c|c|c|c|}
\hline \multirow[b]{2}{*}{$\begin{array}{l}\text { CMMI } \\
\text { Practices }\end{array}$} & \multicolumn{19}{|c|}{ Scrum Practices } \\
\hline & 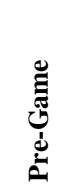 & 咅 & 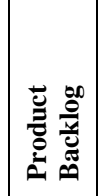 & 竞 & 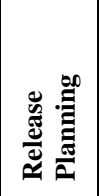 & 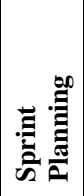 & 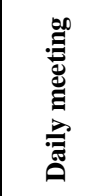 & 言离 & 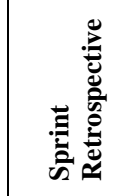 & 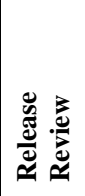 & 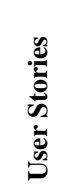 & 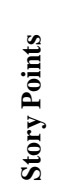 & 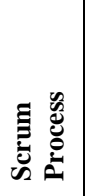 & $\frac{2}{0}$ & 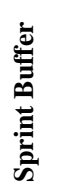 & 鞄 & 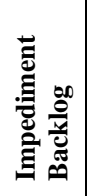 & 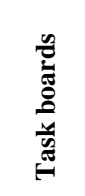 & 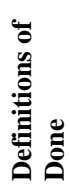 \\
\hline \multicolumn{20}{|l|}{ PMC } \\
\hline SP 1.1 & & & & & & & $x$ & & $x$ & & & & & & & $x$ & & & \\
\hline$S P 1.2$ & & & & & & $x$ & $x$ & $x$ & & & & & & & & $x$ & & & \\
\hline SP 1.3 & & & & & & & $x$ & & $x$ & & & & & & & & & & \\
\hline \multicolumn{20}{|l|}{ SP 1.4} \\
\hline SP 1.5 & & & & & & & . & & & & & & & & & & $x$ & & \\
\hline SP 1.6 & & & & & $x$ & & $x$ & $x$ & $x$ & & & & & & & $x$ & & $\bar{x}$ & \\
\hline SP 1.7 & & & & & & & & $x$ & & $x$ & & & & & & & & & \\
\hline SP 2.1 & & & & & & & $x$ & & $x$ & & & & & & & & $x$ & $\bar{x}$ & \\
\hline$S P$ 2.2. & & & & & & & $x$ & & $x$ & & & & & & & & & & \\
\hline SP 2.3 & & & & & & & & & & & & & & & & & $x$ & $x$ & \\
\hline \multicolumn{20}{|l|}{ REQM } \\
\hline SP 1.1 & & & $x$ & $x$ & $x$ & $x$ & $x$ & $x$ & $x$ & $x$ & $x$ & & & & & & & & \\
\hline SP 1.2 & & & & $x$ & $x$ & & & & & & & & & & & & & & \\
\hline$S P 1.3$ & & & $x$ & & & $x$ & & & & & & & & & & & & & \\
\hline$S P 1.4$ & & & & & & $x$ & $x$ & & & & & & & & & & & & \\
\hline SP 1.5 & & & $x$ & $x$ & & & & & & & & & & & & & & & $x$ \\
\hline \multicolumn{20}{|l|}{ IPM } \\
\hline SP 1.6 & & & & & & & & & & & & & $x$ & & & & & & \\
\hline$S P 2.1$ & & & & & & & & & & & & & $x$ & & & & & & \\
\hline$S P 2.2$ & & & & & & & $x$ & & & & & & & & & & & & \\
\hline SP 2.3 & & & & & & & $x$ & & & & & & & & & & & & \\
\hline \multicolumn{20}{|l|}{ RSKM } \\
\hline$S P 2.1$ & & & & & |x & x & $x$ & |x & $x$ & & & & & & & & & & \\
\hline
\end{tabular}

Fig. 2. Mapping matrix of suitable scrum practices to the PMC, REQM, IPM, and RSKM specific practice of CMMI-Dev

Step 3: Discovering the prior Scrum practice in the mapping
Table 6 shows the number of CMMI specific practices that is supported by each scrum practice. The third row in the table 
shows a Mapping Importance Score (MIP), which is an index score that has been designed in the study in order to discover what are the prior scrum practices when implementing CMMI Project Management category using scrum practices. It is clear from the table that the top five prior scrum practices are;
Sprint Planning, daily meeting, sprint retrospective, release planning, and product backlog. The index assigns 3 points for $\mathrm{S}$ satisfaction rating whiling assigning only 1 point for PS rating.

TABLE IX. MAPPING IMPORTANCE SCOPE AND THE RESULTING RANK

\begin{tabular}{|c|c|c|c|c|c|c|c|c|c|c|c|c|c|c|c|c|c|c|c|}
\hline & \multicolumn{19}{|c|}{ Scrum Practices } \\
\hline & 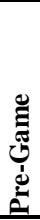 & 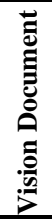 & 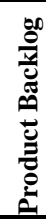 & 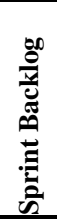 & 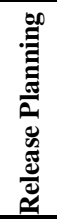 & 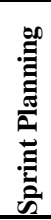 & 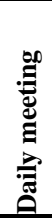 & 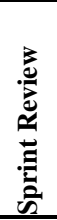 & 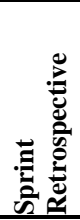 & 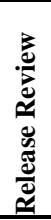 & 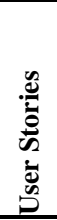 & 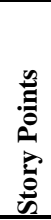 & 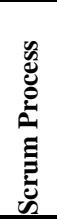 & $\frac{3}{\frac{3}{e}}$ & 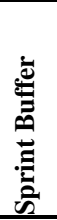 & 苞 & 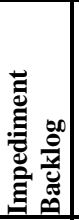 & 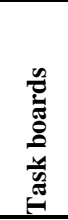 & 递 \\
\hline $\begin{array}{l}\text { CMMI } \\
\text { Specific } \\
\text { Practices } \\
\text { Covered }\end{array}$ & 2 & 1 & 5 & 4 & 8 & 12 & 12 & 6 & 10 & 2 & 2 & 2 & 4 & 1 & 1 & 3 & 3 & 3 & 1 \\
\hline $\begin{array}{l}\text { Fully } \\
\text { Satisfied } \\
\end{array}$ & 2 & 1 & 5 & 4 & 5 & 9 & 5 & 4 & 5 & 2 & 2 & 1 & 4 & 0 & 0 & 2 & 2 & 2 & 1 \\
\hline $\begin{array}{l}\text { Partially } \\
\text { Satisfied }\end{array}$ & 0 & 0 & 0 & 0 & 3 & 3 & 7 & 2 & 5 & 0 & 0 & 1 & 0 & 1 & 1 & 1 & 1 & 1 & 0 \\
\hline $\begin{array}{l}\text { Mapping } \\
\text { Importance } \\
\text { Score(MIP) }\end{array}$ & 6 & 3 & 15 & 12 & 18 & 30 & 22 & 14 & 20 & 6 & 6 & 4 & 12 & 1 & 1 & 7 & 7 & 7 & 3 \\
\hline Index Rank & 9 & 10 & 5 & 7 & 4 & 1 & 2 & 6 & 3 & $9 *$ & $9 *$ & 10 & $7 *$ & 11 & 11 & $8^{*}$ & $8^{*}$ & $8 * *$ & 10 \\
\hline
\end{tabular}

Step 4: Calculating the degree of scrum practices to CMMI SP

Each practice was rated according to the ratings in Table 7 [32]. For a certain rating $\mathrm{i}(\mathrm{i}=1 \ldots \mathrm{n})$ and a process area $\mathrm{j}$ $(j=1 \ldots m)$, we have number of practices $X_{i, j}$. So, the present for ratings can be calculated as follows:

$$
P_{i}=\frac{x_{i, j}}{\sum_{i=1}^{n} \mathrm{x}_{i, j}} \times 100 \%
$$

Also, the total percent for all the process areas is given by

$$
P_{j}=\frac{X_{i, j}}{\sum_{j=1}^{\mathrm{m}} \mathrm{x}_{i, j}} \times 100 \%
$$

TABLE X. ShOWS AN INDEX OF PRACTICES RATING

\begin{tabular}{|l|l|}
\hline Rating & Criteria \\
\hline Satisfied (S) & $\begin{array}{l}\text { Means that CMMI practice is fully addressed by } \\
\text { Scrum practices. }\end{array}$ \\
\hline $\begin{array}{l}\text { Partially Satisfied } \\
\text { (PS) }\end{array}$ & $\begin{array}{l}\text { Means that some parts of CMMI practice is } \\
\text { addressed by Scrum practices. }\end{array}$ \\
\hline Unsatisfied (U) & $\begin{array}{l}\text { Means that CMMI practice is not addressed by } \\
\text { Scrum practices. }\end{array}$ \\
\hline
\end{tabular}

The following gives a summary on the covered specific practices of CMMI Project Management process areas by Scrum practices. Tables 8 shows the results of mapping scrum practices to the CMMI specific practices of the project management related specific areas (i.e. PP, PMC, REQM, SAM, RSKM, IPM and QPM). Table 9 explains this through depicting the coverage percentage per process area. A complete view of the CMMI Project Management process areas covered by Scrum practices is shown in Figure 3. This result shows that $37 \%$ of specific practices of CMMI project management process areas are satisfied, $17 \%$ are partially satisfied and $46 \%$ are unsatisfied. In other words, CMMI project management process areas are not fully covered with Scrum practices mainly related to SAM, RSKM, IPM and QPM process areas.

TABLE XI. COVERAGE OF CMMI PROCESS AREAS By APPLYING THE RECOMMENDED SCRUM PRACTICES

\begin{tabular}{|l|l|l|l|l|l|l|l|l|}
\hline & PP & PMC & REQM & SAM & IPM & RSKM & QPM & Total \\
\hline Satisfied & 10 & 5 & 5 & 0 & 2 & 0 & 0 & 22 \\
\hline $\begin{array}{l}\text { Partially } \\
\text { Satisfied }\end{array}$ & 3 & 4 & 0 & 0 & 2 & 1 & 0 & 10 \\
\hline Unsatisfied & 1 & 1 & 0 & 6 & 6 & 6 & 7 & 27 \\
\hline
\end{tabular}

TABLE XII. COVERAge Percentage of CMmi Process AREAS By APPLYING THE RECOMMENDED SCRUM PRACTICES

\begin{tabular}{|l|l|l|l|l|l|l|l|l|}
\hline & PP & PMC & REQM & SAM & IPM & RSKM & QPM & Total \\
\hline Satisfied & $72 \%$ & $50 \%$ & $100 \%$ & $0 \%$ & $20 \%$ & $0 \%$ & $0 \%$ & $37 \%$ \\
\hline $\begin{array}{l}\text { Partially } \\
\text { Satisfied }\end{array}$ & $21 \%$ & $40 \%$ & $0 \%$ & $0 \%$ & $20 \%$ & $14 \%$ & $0 \%$ & $17 \%$ \\
\hline Unsatisfied & $7 \%$ & $10 \%$ & $0 \%$ & $100 \%$ & $60 \%$ & $86 \%$ & $100 \%$ & $46 \%$ \\
\hline
\end{tabular}

Considering each CMMI project management process areas according to its maturity level, another analysis can be made as shown in Figure 4. Table 10 and Table 11 show the results of the mapping for CMMI project management process areas, grouped by maturity level. In this way, process areas related to maturity level 2 (PP, PMC, RQM and SAM) have $57 \%$ of its specific practices satisfied by Scrum, $20 \%$ are partially satisfied and $23 \%$ are unsatisfied. If SAM are not considered, Scrum becomes more compliant with level 2 without major adaptations (69\% satisfied, $24 \%$ partially satisfied and $7 \%$ unsatisfied). 


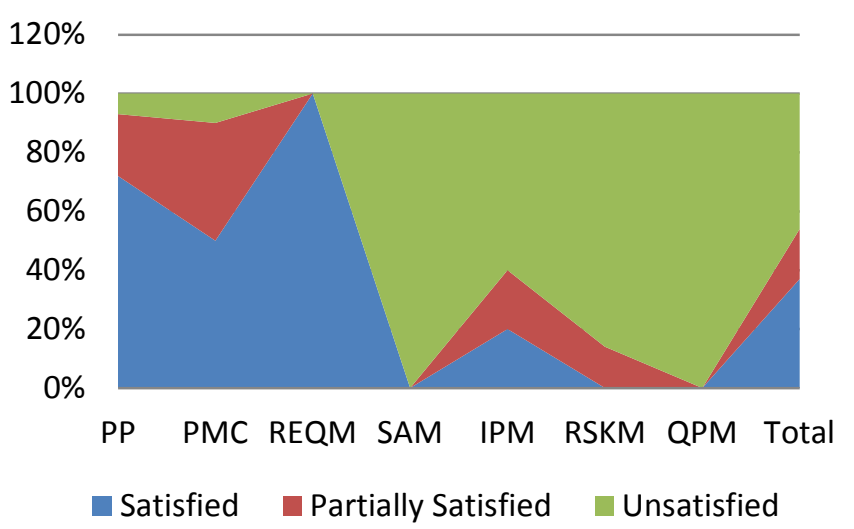

Fig. 3. General Result from the Mapping

TABLE XIII. CMMI ProjeCt ManAgEMENT Process AREAS Covered By APPLYING THE RECOMMENDED SCRUM PRACTICES, GROUPED BY MATURITY LEVEL

\begin{tabular}{|l|l|l|l|}
\hline & $\begin{array}{l}\text { PM Category } \\
\text { Level 2 }\end{array}$ & $\begin{array}{l}\text { PM Category } \\
\text { Level 3 }\end{array}$ & $\begin{array}{l}\text { PM Category } \\
\text { Level 4 }\end{array}$ \\
\hline Satisfied & 20 & 2 & 0 \\
\hline Partially Satisfied & 7 & 3 & 0 \\
\hline Unsatisfied & 8 & 12 & 7 \\
\hline
\end{tabular}

TABLE XIV. Coverage Percentage of CMMI Process AREAS by APPLYING THE RECOMMENDED SCRUM PRACTICES, GROUPED BY MATURITY LEVEL

\begin{tabular}{|l|l|l|l|}
\hline & $\begin{array}{l}\text { PM Category } \\
\text { Level 2 }\end{array}$ & $\begin{array}{l}\text { PM Category } \\
\text { Level 3 }\end{array}$ & $\begin{array}{l}\text { PM Category } \\
\text { Level 4 }\end{array}$ \\
\hline Satisfied & $57 \%$ & $12 \%$ & $0 \%$ \\
\hline Partially Satisfied & $20 \%$ & $18 \%$ & $0 \%$ \\
\hline Unsatisfied & $23 \%$ & $70 \%$ & $100 \%$ \\
\hline
\end{tabular}

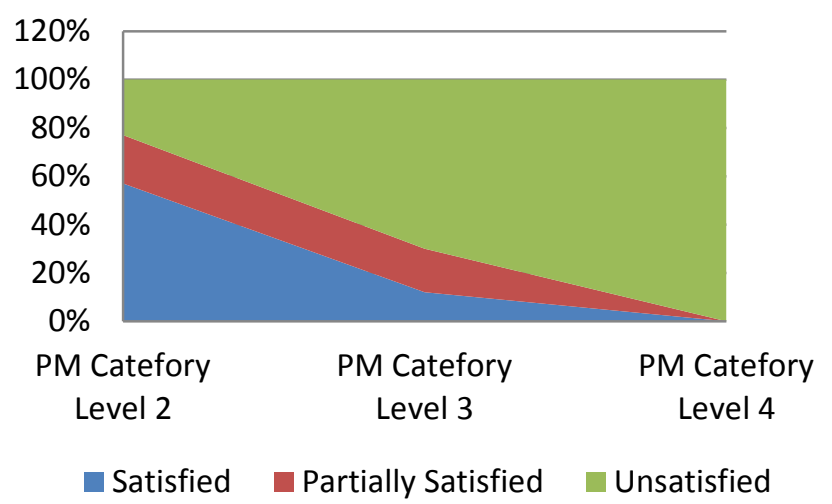

Fig. 4. General Result from the Mapping on PM Category, Grouped by Maturity Levels

With regard to process areas related to maturity level 3 (IPM and RSKM), these process areas have $12 \%$ of its specific practices satisfied by Scrum, $18 \%$ are partially satisfied and $70 \%$ are unsatisfied due to the lack of practices for managing risks and the absence of a defined process derived from a set of organizational processes. Finally, process areas related to maturity level 4 (QPM) are unsatisfied because Scrum does not mention practices to address these process areas.
The major gaps between Scrum and PP, PMC, REQM, SAM, RSKM, IPM and QPM process areas are presented below:

- Scrum framework does not provide explicit description for planning and controlling of project's budget, affecting PP and PMC.

- Scrum framework does not explicitly address calculation of project's costs, affecting PP and PMC.

- Lack of practices for managing risks, affecting RSKM, PP and PMC practices.

- Scrum framework does not include any practices for planning and tracking data management, affecting PP and PMC practices.

- Scrum does not define a set of organizational standard processes, but it just establishes a set of practices and rules defined for the project, affecting IPM practices.

- Scrum does not mention practices to address the acquisition of products from suppliers. So, all SAM specific practices are unsatisfied.

- Scrum has no practices to address the QPM process area, so all its practices are unsatisfied.

\section{RESULTS DISCUSSION, AND FUTURE WORK}

\section{A. Results Discussion}

based on the above, Figure 5 and Figure 6 shows a comparison between our overall results of the mapping and those of Marcal et al [32].

It should be noted that the mapping between the specific practices of the CMMI process areas and Scrum practices according to Marcal et al. considers the staged representation of CMMI-DEV version 1.2, but our work considers the CMMI-DEV version 1.3 which is the latest version till now. Working with older versions of CMMI-DEV will not be of a much help to the new companies that are looking for a CMMI certification.

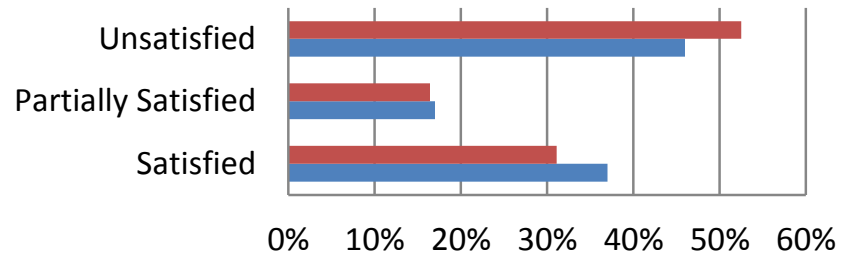

\begin{tabular}{|l|c|c|c|}
\cline { 2 - 4 } \multicolumn{1}{c|}{} & Satisfied & $\begin{array}{c}\text { Partially } \\
\text { Satisfied }\end{array}$ & Unsatisfied \\
\hline Marcal et al. & $31 \%$ & $16 \%$ & $53 \%$ \\
\hline Our Work & $37 \%$ & $17 \%$ & $46 \%$ \\
\hline
\end{tabular}

Fig. 5. A Comparison between Our Overall Results of the Mapping for PM category and Those of Marcal et al., Considering CMMI Version 1.2 


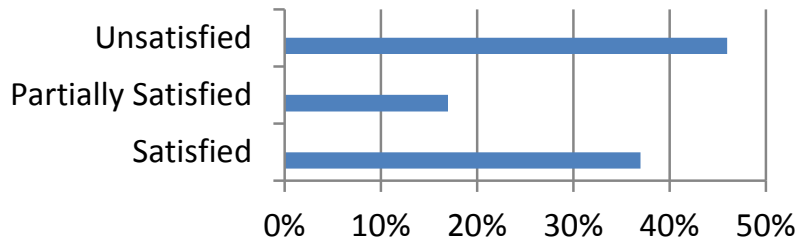

\begin{tabular}{|l|c|c|c|}
\cline { 2 - 4 } \multicolumn{1}{c|}{} & Satisfied & $\begin{array}{c}\text { Partially } \\
\text { Satisfied }\end{array}$ & Unsatisfied \\
\hline$\square$ Marcal et al. & $0 \%$ & $0 \%$ & $0 \%$ \\
\hline$\square$ Our Work & $37 \%$ & $17 \%$ & $46 \%$ \\
\hline
\end{tabular}

Fig. 6. A Comparison between Our Overall Results of the Mapping and Those of Marcal et al., Considering CMMI Version 1.3

\section{B. Future Work}

More work will be done to deliver a scrum coverage for other process areas that have not been covered on this paper (i.e SAM, RSKM, and QPM). Since SAM is highly required nowadays due to the increasing size of the outsourcing engagements in the software development industry [38], automating SAM within Scrum process could be a good start for the future work since it is unclear area in the integration between CMMI and Scrum.

\section{CONCLUSION}

In our previous research work [7], it was shown that working with agile could cover a portion of the CMMI specific practices with applying some non-scrum practices. This study proposed a new way to use the simpler scrum practices and assets in order to satisfy the more complicated CMMI-Dev version 1.3's specific practices. This leads to satisfying the CMMI generic practices thus, satisfying the CMMI process areas. The coverage that this work has achieved haven't been achieved for any previous similar work. Additionally, other older efforts haven't worked on the currently used CMMI version (1.3). This research has been conducted to delve in more details concerning the important scrum practices that could be improved using existing scrum assets to streamline CMMI specific practices implementation in the Project Management category, and what could be the effect of that on the overall scrum coverage of the CMMI specific practices. This research has designed a new score index that could measure the importance of specific Scrum practices in the CMMI practices coverage (MIP Score Index). This score index showed that the top five practices that should be always improved to enhance the CMMI coverage were in order; Sprint Planning, Daily meeting, sprint retrospective, release planning, and product backlog. After applying improvements on these practices in 6 different CMMI appraised companies in Egypt some positive results have been concluded compared to other previous research efforts that have been done by Marcal et al. The work that has been done by Marcal et al. has been done in the same context but with two shortcomings. The first is that it was not updated for CMMI version 1.3. This shortcoming means that it couldn't help teams that will be appraised based on this version. The second shortcoming is that it did not provide enough coverage of Scrum practices to CMMI version 1.3 specific practices. Our research has resulted in delivering a better satisfaction with additional $6 \%$ coverage, which is $19.4 \%$ development. Moreover, this research increased the level of scrum partial satisfaction coverage of the CMMI practices by extra $\% 1$ which resembles $6.2 \%$ development percentage. In addition to that, previous work did not consider CMMI version 1.3. That is why, if compared to the version 1.3, the comparison percentages will be against $0 \%$ enhancements from Marcal's previous work.

The conclusion is that CMMI and Scrum method can work well together, and both approaches can bring more benefits than either one alone. So, Scrum method provides good practices for streamlining CMMI project management process areas related to maturity level 2 , and 3 . On process areas related to level 4, Scrum method covers only a little part of these areas. Other alternative practices are necessary to make these two approaches more compliant. This alternative is useful for companies that are adopting agile methods while searching for a CMMI certification.

\section{REFERENCES}

[1] A. Preis, "Integration Evaluation of Scrum and CMMI," Organizational Science, 2012.

[2] "Manifesto for Agile Software Development," 29 November 2013. [Online]. Available: http://agilemanifesto.org.

[3] A. Garg, "Agile software development," DRDO Science Spectrum, pp. 55-59, March 2009.

[4] M. Pikkarainen and A. Mäntyniemi, "An Approach for Using CMMI in Agile Software Development Assessments: Experiences from Three Case Studies," in SPICE, 2006.

[5] H. Glazer, "Agile CMMI: Why Isn't This Conversation Dead Yet?," Cutter IT Journal, vol. 25, no. 11, November 2012.

[6] H. Glazer et al, "CMMI or Agile?: Why Not Embrace Both?!," Carnegie Mellon University, Software Engineering Institute, Nov, 2008.

[7] "SIMPLIFYING CMMI VERSION 1.3 IMPLEMENTATION BY USING AGILE," International Journal of Intelligent Computing and Information Sciences (IJICIS), vol. 14, no. 4, pp. 31-45, October 2015.

[8] Irrazabal, E., et al, "Applying ISO/IEC 12207:2008 with SCRUM and Agile Methods," in 11th International Conference, SPICE, 2011.

[9] "CMMI Institute," [Online]. Available: http://cmmiinstitute.com/. [Accessed 29 April 2013].

[10] M. B. Chrissis et al.,, CMMI for Development, Addison-Wesley, 2011.

[11] D. L. Giudice, "The 2015 State Of Agile Development," Forrester Research, August 3, 2105.

[12] CMMI Product Team, "CMMI for Development, Version 1.3," Software Engineering Institute, Carnegie Mellon University, Pittsburgh, Pennsylvania, 2010.

[13] SCAMPI Upgrade Team, Standard CMMI Appraisal Method for Process Improvement (SCAMPI) A, Version 1.3: Method Definition Document, Pittsburgh, Pennsylvania: Software Engineering Institute, Carnegie Mellon University, 2011.

[14] M. Staples and M. Niazi, "Two case studies on small enterprise motivation and readiness for CMMI," in 11th International Conference on Product Focused Software Development and Process Improvement, 2010.

[15] K. M. Calo et al, "A Quantitative framework for the evaluation of agile methodologies," JCS\&T, vol. 10, no. 2, 2 June 2010.

[16] "Agile Alliance," 10 January 2013. [Online]. Available: http://www.agilealliance.org/.

[17] k. Pathak and A. Saha, "Review of Agile Software Development Methodologies," International Journal of Advanced Research in Computer Science and Software Engineering (IJARCSSE), vol. 2, 2013. 
[18] B. N. Nathan-Regis and V. Balaji, "Evaluation of the most used agile methods (XP, Lean, Scrum)," International Journal of Engineering Science and Technology (IJEST), vol. 4, no. 1, January 2012.

[19] M. Hneif and S. Hock, "Review of agile methodologies in software development," International Journal of Research and Reviews in Applied Sciences, vol. 1, October 2009.

[20] M.Qasaimeh et al, "Comparing Agile Software Processes Based on the Software Development Project Requirements," IEEE Computer Society, p. 2008.

[21] "Scrum Alliance," 2 March 2013. [Online]. Available: http://www.scrumalliance.org/.

[22] CMMI Product Team, "CMMI for Development Quick Reference," $\begin{array}{llll}\text { November } & 2010 . & \text { [Online]. } & \text { Available: }\end{array}$ http://cmmiinstitute.com/assets/CMMI-DEV_Quick_Ref.pdf.

[23] J. Sutherland, Scrum Handbook, Scrum Training Institute, July, 2010.

[24] N. Potter and M. Sakry, "Scrum - Lessons From The Trenches," The Process Group-Post Newsletter, vol. 19, no. 1, 2012.

[25] K. Schwaber, "Agile Project Management with Scrum," Microsoft, 2004.

[26] Microsoft Team, "MSF for Agile Software Development v5.0," Microsoft, May 2010. [Online]. Available: http://msdn.microsoft.com/en-us/library/dd380647(v=vs.100).aspx .

[27] K. Schwaber and J. Sutherland, "The Scrum Guide.," October 2011. [Online]. Available: http://www.scrum.org/Portals/0/Documents/Scrum\%20Guides/Scrum_G uide.pdf\#zoom=100.

[28] M. Foegen, "Scrum and CMMI - Does it fit together?," wibas GmbH, $\begin{array}{lll}\text { November } & 2010 . & \text { [Online]. }\end{array}$ http://www.wibas.com/publications/scrum/scrum_and_cmmi/index_en.h tml.

[29] C. R. Jakobsen and J. Sutherland, "Scrum and CMMI Going from Good to Great," in Agile Conference, 2009.

[30] H. Glazer, "Love and marriage: CMMI and Agile Need Each Other," CROSSTALK: The Journal of Defense Software Engineering, 2010.

[31] M. Fritzsche and P. Keil, "Agile Methods and CMMI: Compatibility or Conflict," e-Informatica Software Engineering Journal, vol. 1, 2007.

[32] A. S. C. Marcal et al, "Mapping CMMI project Management Process Areas to Scrum Practices," in 31st IEEE Software Engineering Workshop (SEW 2007), 2007.

[33] J. Diaz et al., "Mapping CMMI Level 2 to Scrum Practices: An Experience Report," EuroSPI, 2009.

[34] N. Potter and M. Sakry, "Implementing Scrum (Agile) And CMMI® Together," The Process Group-Post Newsletter, vol. 16, no. 2, 2009.

[35] P. Abrahamsson et al, "Agile Software Development Methods," 2002. [Online].

[36] M. Foegen and D. Croome, "How Scrum helps with CMMI," wibas $\mathrm{GmbH}$, Febreuary 2011. [Online]. Available: http://www.wibas.com/publications/cmmi/cmmi_and_scrum/index_en.h tml.

[37] B. Reddaiah et al., "Risk Management Board for Effective Risk Management in Scrum," International Journal of Computer Applications, vol. 65, no. 12, p. 0975 - 8887, March 2013.

[38] S. Islam and M. D. Ahmed, "Business process improvement of credit card department: case study of a multinational bank," Business Process Management Journal, vol. 18, pp. 284 - 303, 2012. 